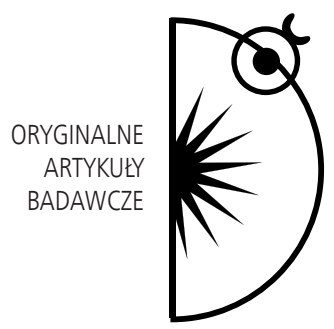

Agnieszka Kinas-Zalewska

\title{
GST - ogólna teoria napięcia a nieletni sprawcy przestępstw seksualnych
}

DOI: http://dx.doi.org/10.12775/PBE.2013.017

Statystyki policyjne dowodzą, iż przestępstwo zgwałcenia było w latach 2002-2011 popełniane przez osoby nieletnie średnio 16 razy częściej niż zabójstwo $^{1}$. Należy jednak uwzględnić tzw. czarną liczbę w przypadku przestępstwa zgwałcenia i podejrzewać, iż różnica ta jest jeszcze większa. Fakt ten rodzi konieczność podjęcia działań prewencyjnych, wskazuje także potrzebę poddania owych nieletnich oddziaływaniom resocjalizacyjnym.

W rodzimej pedagogice resocjalizacyjnej zagadnienie przestępstw seksualnych popełnianych przez osoby nieletnie nie cieszyło się dotąd większym zainteresowaniem. Prace Starowicza (2007) czy Pospiszyla (2005) traktuja co prawda o sprawcach przestępstw seksualnych, jednakże dotyczą głównie dorosłych. Niewielki odsetek badanych przez Starowicza osób nie ukończył 25 lat, jednak nie można uznać, iż są to osoby nieletnie, bowiem ich wiek nie został jednoznacznie określony. Pospiszyl natomiast dość pobieżnie przytacza wybrane wyniki badań amerykańskich i szwedzkich. Część prezentowanych badań nie opiera się na naukowych teoriach. Zdarza się także, iż wyniki są rezultatem analizy wyłącznie akt sądowych (Marzec-Holka, 2011). Z całą pewnością nie mogę wskazać książki czy chociażby artykułu, które prezen-

\footnotetext{
${ }^{1} \mathrm{http}: / /$ statystyka.policja.pl/st/wybrane-statystyki/przestepczosc-nieletni/50256, PRZESTEPCZOSC-NIELETNICH-w-LATACH-1990-2012.html (dostęp: 15.10.2013).
} 
towałyby badania empiryczne z zakresu przestępczości seksualnej popełnianej przez osoby nieletnie, przy jednoczesnym osadzeniu projektu w naukowej teorii oraz przedstawieniu autorskich rozwiązań resocjalizacyjnych.

Jako że dewiacje i przestępstwa seksualne stanowią dla mnie - jako badacza - interesujące kwestie społeczne, jednocześnie nauka wykazuje w tej tematyce spore braki, dodatkowo jest to problem aktualny i ważny - zdecydowałam, iż czyny karalne o znamionach przestępstw seksualnych, popełniane przez nieletnich, staną się przedmiotem moich rozważań. W tym miejscu chciałabym przejść do omówienia kilku ważnych kwestii związanych z owym zagadnieniem.

\section{Regulacje prawne dotyczące przestępstw przeciwko wolności seksualnej}

Rozdział XXV Kodeksu karnego prezentuje unormowania dotyczące tzw. przestępstw seksualnych, gdzie pojęcie to nie jest jednoznaczne. $Z$ jednej strony możemy mówić o ujęciu prawno-dogmatycznym, z drugiej zaś o kryminologicznym. Oba niosą za sobą pewne mankamenty. W pierwszym przypadku ograniczamy się do przestępstw ujętych w jednym rozdziale Kodeksu karnego, w ujęciu kryminologicznym natomiast zasadniczą rolę odgrywa motywacja sprawcy rozumiana jako dążenie do pobudzenia lub zaspokojenia popędu seksualnego - niekoniecznie samego sprawcy. Przestępstwa seksualne możemy także podzielić na te o charakterze subiektywnym bądź obiektywnym. W subiektywnym ujęciu sprawca narusza wolność seksualną ofiary, bez względu na metodę działania i skutek. Obiektywny charakter przypisuje się natomiast działaniom naruszającym dobro prawne (Wąsek, 2006).

By uniknąć terminologicznego chaosu, pod pojęciem przestępstw seksualnych będę rozumieć te czyny, o których traktuje rozdział XXV Kodeksu karnego, mimo iż nie zawiera on wszystkich czynów zabronionych, które można by zaliczyć do przestępstw seksualnych. Ponadto nie wszystkie wymienione $\mathrm{z}$ tym rozdziale przestępstwa są dla mnie - jako badacza - istotne. Pomijam art. 202-204, a także 205, który odnosi się do trybu ścigania. W projektowanym badaniu zatem istotne są dla mnie następujące czyny popełniane przez osoby nieletnie (13-21 lat):

- zgwałcenie i wymuszenie czynności seksualnej (art. 197 kk),

- seksualne wykorzystanie niepoczytalności lub bezradności (art. 198 kk),

- seksualne wykorzystanie zależności (art. 199 kk), 
- seksualne wykorzystanie małoletniego (art. 200, art. 200 lit. a, art. 200 lit. b kk),

- kazirodztwo (art. $201 \mathrm{kk}$ ) (Bojarska, 2012).

Nie sposób w tak krótkim opracowaniu zacytować wszystkie wyżej wymienione artykuły i opatrzyć je komentarzem. Ponadto nie jest to tekst z zakresu prawa karnego. Skupię się więc tylko na kilku ważniejszych terminach: „obcowanie płciowe”, ,inna czynność seksualna” oraz „doprowadzenie do".

Obcowanie płciowe obejmuje nie tylko heteroseksualny akt spółkowania (immisio penis), ale także inne zachowania o charakterze seksualnym, które stanowią surogaty takiego spółkowania i które sprawca traktuje ekwiwalentnie. Zachowania te polegają na bezpośrednim kontakcie płciowych części ciała (pomiędzy sprawcą a ofiarą), np. stosunek oralny bądź analny (Filar, 1999), nawet jeśli nie dochodzi do ejakulacji (emmisio seminis). Mowa również o stosunkach homoseksualnych oraz kontaktach z dziećmi o niewykształconych jeszcze narządach płciowych (Wojciechowski, 2000).

Przez inne czynności seksualne należy rozumieć zachowania o seksualnej inspiracji oraz treści, polegające na cielesnym kontakcie sprawcy i ofiary lub seksualnym zaangażowaniu ofiary, np. zmuszanie jej do onanizowania sprawcy, „obmacywanie” ofiary w okolicach jej narządów płciowych czy też zmuszanie jej do obnażania się lub masturbacji (Góral, 1998). Inne czynności seksualne obejmują nie tylko fizyczne, ale również intelektualne zaangażowanie ofiary (Wąsek, 2006).

Znamię „doprowadza do” jest czytelne w przypadku artykułów: 197, 198 oraz 199 Kodeksu karnego. Zostały tam wyartykułowane trzy sposoby owego „doprowadzania”: przemoc, groźba bezprawna i podstęp. Wątpliwości pojawiają się natomiast w przypadku art. 200, bowiem sam wyraz „doprowadzać do" jest aksjologicznie neutralny, oznacza tyle, co 'wywołać', 'spowodować', 'być przyczyną czegoś'. Człon „dopuszcza się” sygnalizuje przestępstwo własnoręczne (odbywane z ofiarą obcowanie płciowe lub inną czynność seksualną), natomiast „doprowadza ją do poddania się takim czynnościom” nie oznacza własnoręczności, mimo iż najczęściej ten, kto doprowadza do czynu jednocześnie dopuszcza się go. Jednakże z normatywnego punktu widzenia nie zawsze ma to miejsce. Sprawcą czynów, o których mowa w art. 200 kk, jest nie tylko osoba dopuszczająca się wspomnianych czynów, ale także jednostka, która kusi, namawia, szantażuje... (Filar, 2004). Z kręgu zachowań penalizowanych wobec przyjętej wykładni art. $200 \mathrm{kk}$ należy wykluczyć np. ekshibicjonizm oraz onanizowanie się na oczach małoletniego, jednakże doprowadzenie go do takich czynności już nie (Marek, 2000), bowiem jest to przejaw podjętej przez 
sprawcę aktywności warunkującej wolę małoletniego (Góral, 2005). W myśl znowelizowanego kodeksu karnego podjęcie owych czynności wyłącznie z inicjatywy małoletniego nie jest uznane za przestępstwo (Mozgawa, 2006).

\section{Napięcie motywacyjne}

Istotnym zagrożeniem dla badań, zarówno w naukach społecznych, jak i humanistycznych, jest uwikłanie ich w ideologię. Skazą może być również ich socjograficzny charakter. Z jednej strony mankamentem jest ateoretyczność badania empirycznego, z drugiej zaś przedteoretyczność. Aby tego uniknąć, swój projekt badawczy osadzam w konkretnej koncepcji teoretycznej. Nim jednak przejdę do jej rekonstrukcji - omówię kluczowe dla niej pojęcie, jakim jest napięcie motywacyjne.

Napięcie motywacyjne jest stanem, w którym aparat regulacji zostaje pobudzony i objawia się dążeniem do podjęcia aktywności, niekoniecznie ściśle sprecyzowanej. Zostają pobudzone jednostki motoryczne, następuje wzmożenie tonusu mięśniowego (Reykowski, 1979).

Istnieje nie do końca zbadana zależność między napięciem motywacyjnym a emocjami. W sytuacji, gdy jednostka nie może zredukować napięcia motywacyjnego przez wykonanie jakiejś czynności - powstaje emocja, mająca tym większe natężenie, im wyższy jest poziom napięcia. Nie wiadomo jednak, czy podjęcie działania wiąże się ze spadkiem emocji. Napięcie to jest odczuwane jako chęć podjęcia aktywności. Tylko doświadczona osoba, znająca strategie redukowania napięcia, może je wyrazić w formie intencyjnej czy też życzeniowej. Ponadto napięcie może być zarówno dodatnie, jak i ujemne (Reykowski, 1979). Dla potrzeb artykułu omówię tylko ten drugi rodzaj.

Ujemne napięcie motywacyjne pojawia się w sytuacjach niezaspokojenia potrzeb jednostek, gdy coś/kogoś tracą, ulegają wpływom czynników szkodliwych, doznają niepowodzeń, stają się ofiarami, obiektami zagrożenia. Jest ono odczuwane przez jednostkę jako cierpienie, frustracja, obawa, poczucie bra$\mathrm{ku} / \mathrm{utraty} /$ pozbawienia. Istotne jest to, iż wydarzenia rodzące te stany nie muszą dotyczyć samej jednostki. Mogą odnosić się do zinternalizowanych norm i wartości lub też osób/grup, z którymi się solidaryzują, zarówno w przypadku pozbawienia przywilejów, jak i ataku. Wysokość napięcia motywacyjnego jest uwarunkowana czasem deprywacji danych potrzeb. Im dłuższy czas deprywacji - tym większe napięcie motywacyjne. Jednakże jeżeli dana potrzeba jest niezaspakajana nazbyt długo - napięcie nie wzrasta, można nawet zaobserwo- 
wać jego spadek. Nie ma to jednak miejsca w sytuacjach, gdy deprywacja jest sporadycznie zaspakajana (Reykowski, 1979).

Reykowski wymienia kilka form redukcji napięcia motywacyjnego:

- osiągnięcie przez daną osobę takiego stanu rzeczy, który redukuje owe napięcie (posiada wartość gratyfikacyjną), podjęcie czynności konsumacyjnych (redukujących napięcie),

- spontaniczny spadek napięcia związany z długotrwałym jego występowaniem (np. na skutek wyczerpania mechanizmów regulacyjnych),

- zmiany poziomu napięcia na skutek zmian ustrojowych,

- usuwanie jednego napięcia przez inne, silniejsze,

- redukcja napięcia na skutek działania silnych bodźców negatywnych i odpowiadających im reakcji gwałtownych,

- redukcja napięcia związana z wpływem czynników biochemicznych (leki, alkohol, narkotyki) (Reykowski, 1979).

Gdy powyższe formy redukcji napięcia motywacyjnego (za wyłączeniem pierwszego) zaczynają dominować - następuje degradacja psychiki jednostki (Reykowski, 1979).

\section{GST - ogólna teoria napięcia Roberta Agnew}

GST wyjaśnia podłoże zachowań przestępczych oraz zażywania narkotyków przez osoby nieletnie. Stanowi ona alternatywę dla teorii społecznej kontroli oraz teorii zróżnicowanych powiązań. Jej charyzma kryje się w tym, że jako jedyna skupia się na relacjach negatywnych, które „popychają” do zachowań przestępczych (Agnew, White, 1992).

Istotnym pojęciem w tej teorii jest „napięcie motywacyjne”, które dokładnie omówiłam we wcześniejszej części artykułu. Agnew twierdzi, że napięcie pojawia się, gdy:

- jednostka jest powstrzymywana przed osiąganiem celów dodatnich,

- jednostka jest pozbawiana bodźców dodatnich,

- jednostka staje w obliczu bodźców szkodliwych lub negatywnych (Agnew, White, 1992)

Pierwszy typ napięcia zdobył duże zainteresowanie w dziedzinie kryminologii. Ocenia się go w kategoriach rozbieżności między aspiracjami/idealnymi celami a oczekiwaniami/idealnymi celami. Agnew, podpierając się literaturą na temat sprawiedliwości, twierdzi, że ten typ napięcia można określić w kategoriach rozbieżności pomiędzy (a) oczekiwaniami i rzeczywistymi wynikami a (b) sprawiedliwymi wynikami i faktycznymi rezultatami. Drugi i trzeci typ 
napięcia nie odegrały istotnej $\mathrm{w}$ roli w nauce, jaką jest kryminologia. Utrata bodźców dodatnich może wiązać się np. ze zmianą miejsca zamieszkania czy też śmiercią bliskiej osoby. Stawanie w obliczu bodźców szkodliwych/negatywnych zaś obejmuje różnorodne rodzaje wiktymizacji kryminalnej: negatywne relacje z rodzicami/nauczycielami/rówieśnikami, groźby werbalne i inne stresujące wydarzenia życiowe. Powyższe typy napięcia są czynnikami ryzyka dopuszczania się zachowań przestępczych. Nie bez znaczenia pozostaje powiązanie z grupą rówieśniczą o charakterze przestępczym oraz poczucie samoskuteczności. Zaistnienie u jednostki napięcia motywacyjnego zwiększa ryzyko doświadczenia przez nią takich negatywnych stanów jak: depresja, wściekłość, rozczarowanie. Stany te rodzą presję do podjęcia działań korygujących (Agnew, White, 1992). Nie zawsze jednak są to czyny karalne.

Autor GST wyróżnia trzy typy strategii adaptacji do napięcia:

- strategie poznawcze,

- strategie behawioralne,

- strategie emocjonalne (Agnew, 1992).

Ze strategiami poznawczymi mamy do czynienia w sytuacji, gdy jednostka reinterpretuje przedmiot stresu, przez co zmniejsza odczuwaną krzywdę. Strategie te przyjmują trzy formy:

1. Ignorancja (zmniejszanie wielkości szkody): jednostka okłamuje samą siebie, iż ceniona dotychczas rzecz/wartość/norma/cel nie jest już istotna w sensie absolutnym. Przypomina to wycofanie i rytualizm. Może też stwierdzić, że dana rzecz jest małowartościowa w sensie relatywnym, czyli w stosunku do innych. Zdolność do minimalizowania skutków napięcia jest tu związana $\mathrm{z}$ umiejętnością ulokowania określonych wartości w sferach mało cenionych w życiu.

2. Powiększanie wyników pozytywnych - zmniejszanie negatywnych: jednostka adaptuje się do sytuacji, zaprzeczając istnieniu stresora, maksymalizując wyniki pozytywne i minimalizując negatywne. Osoba taka obniża bądź zniekształca własne oceny w stosunku do określonych wartości, ignoruje cele trudno osiągalne, skupia się na prostszych. Zaniża wartościowanie, by nie czuć się gorsza od innych. Podnosi to jej samoocenę, obniżając jednocześnie poczucie napięcia.

3. Wzięcie na siebie odpowiedzialności za określone nieszczęścia (niepowodzenia): subiektywnie odczuwane napięcie spada, gdy jednostka uświadomi sobie, iż to właśnie ona odpowiada za zaistniałe konsekwencje, na które „,zasłużyła”. Zasłużone cierpienie wydaje się tu mniej bolesne niż niezasłużone. Autor wyróżnia dwie strategie, dzięki którym jednostka 
utwierdza się w przekonaniu, iż jest winna (Agnew, 1992). Pierwsza skupia się na poznawczym pomniejszaniu własnego wartościowego wysiłku bądź też powiększaniu szkodliwego wkładu. Druga zaś polega na wyolbrzymianiu pozytywnego wysiłku innych bądź też pomniejszaniu ich wysiłku negatywnego.

W strategiach behawioralnych wyróżnić należy następujące zachowania:

- wyolbrzymianie wyników wartościowych - pomniejszanie niewartościowych (negatywnych): zachowania redukujące napięcie mogą mieć tu charakter zarówno konwencjonalny, jak i dewiacyjny, w których to jednostka będzie dążyć do doświadczania bodźców pozytywnych, obrony czy też ucieczki,

- odwet (zemsta): w sytuacjach, gdy jednostka za zaistniałą sytuację obwinia nie siebie, lecz innych - będzie dążyć do rewanżu, który może być zarówno konwencjonalny, jak i dewiacyjny; bardziej prawdopodobne jest zachowanie przestępcze; jednostka często pomniejsza pozytywne wyniki i powiększa negatywne innych (obwinianych) (Agnew, 1992).

Ostatnią grupę strategii adaptacji do napięcia stanowią strategie emocjonalne, które sprowadzają się do: relaksacji, biofeedbacku, medytacji lub też zażywania środków psychoaktywnych. Ich rolą jest pomniejszanie negatywnych stanów emocjonalnych. Badania wykazują, iż strategie te są często stosowane przez nieletnich, kiedy pozostałe są nieskuteczne bądź niedostępne (Agnew, 1992).

Jak widać nieletni nie zawsze redukują napięcie, popełniając czyny karalne. Co zatem zwiększa prawdopodobieństwo wyboru strategii dewiacyjnych?

Mertonowskie teorie znalazły się pod obstrzałem ostrej krytyki, gdy ich autor nie potrafił odpowiedzieć na pytanie: dlaczego tylko niektóre osoby wybierają dewiacyjne formy aktywności, dążąc do redukcji napięcia? Agnew odpowiada na nie, odwołując się do teorii stresu, agresji i egalitaryzmu. Podkreśla, że nieszczęśliwa jednostka staje się podniecona, co mobilizuje ją do podjęcia zachowania - przestępczego lub nie, zależnie to od splotu różnych okoliczności. Prawdopodobieństwo wyboru zachowania przestępczego zwiększa się w sytuacji, gdy nieletni ma ubogi wachlarz norm i wartości, celów, które mogłyby stać się swoistym schronieniem, nie ma sfery, do której mógłby „przenieść" napięcie. Oznacza to, że im nieletni ma większe pole zainteresowań i celów życiowych - tym większe jest jego „pole schronienia” dla napięć i hamowanych dążeń. Jest to stwierdzenie bardzo ważne dla profilaktyki i resocjalizacji. Nie bez znaczenia w wyborze zachowań przestępczych pozostają także: umiejętność rozwiązywania problemów, poziom intelektualny, tempe- 
rament, twórczość, umiejętności interpersonalne oraz samoocena. Cechy te odzwierciedlają wrażliwość jednostki na powstałe napięcie, a także kształtują zdolność wyboru strategii redukcji napięcia (emocjonalnych, behawioralnych, poznawczych). Badania wykazują, iż nieletni posiadający wysoką samoocenę lepiej radzą sobie w sytuacjach stresu, co oddala ich od wyboru dewiacyjnych strategii redukcji napięcia. Podobnie jest w przypadku innych wyżej wymienionych cech osobowych. Utrudnieniem natomiast dla podjęcia zachowań przestępczych są koszty oraz konsekwencje takich czynów, społeczna kontrola (jej poziom) oraz często konieczność zdobycia nielegalnych przedmiotów, niezbędnych do tego typu aktów. Wybór przestępczych strategii może być także podyktowany wyuczonymi doświadczeniami, atrybucją dotyczącą własnego cierpienia oraz zinternalizowanymi nieaprobowanymi normami (reakcjami na stres). Ponadto istnieje związek między częstotliwością doznawania krzywdy a dyspozycją do popełniania czynów karalnych - im częstsze poczucie krzywdy, tym więcej dewiacyjnych zachowań (Urban, 2000).

Autor ogólnej teorii napięcia przekonuje, że wiele pośrednich dowodów potwierdza założenia jego teorii. GST jest teorią naukową, jednakże nie posiada gotowego narzędzia badawczego. Żaden kwestionariusz nie obejmuje miar wszystkich typów napięcia zawartych w teorii. Nie zawiera też wskaźników wszystkich zmiennych określających związek pomiędzy napięciem a przestępczością/zażywaniem narkotyków (Agnew, White, 1992). Weryfikacji poddano dwie hipotezy. Wykorzystano do tego zestaw danych opracowanych w Projekcie Zdrowia i Rozwoju Człowieka w Uniwersytecie Rutgers. Zestaw ten zawiera miary wielu typów napięcia oraz wskaźniki istotnych zmiennych, wyodrębnionych przez Agnew. Nie jest to narzędzie doskonałe, brakuje wybranych wskaźników, dlatego też jest to badanie częściowe, niemniej jednak wystarczające do określenia, czy GST to teoria przestępczości, obok teorii uczenia się oraz teorii społecznej kontroli (Agnew, White, 1992).

Prospektywne badanie podłużne dotyczyło nadużywania alkoholu i narkotyków. Zostało przeprowadzone w latach 1979-1981 na grupie 1380 nastolatków w wieku 12, 15 i 18 lat (wywiad). Respondentów wytypowano na zasadzie losowych rozmów telefonicznych. Spośród nich 40\% spełniających warunki respondentów poddano kolejnemu badaniu - wywiadowi w warunkach domowych, sondażom i testom. Wykazano podobieństwo w zakresie religii, rasy oraz zachowania odnoszącego się do picia alkoholu przez „głowę rodziny”. Rodzice osób, które zgodziły się na badanie, posiadali wyższe wykształcenie i większe zarobki niż rodzice tych, którzy odmówili dalszego uczestnictwa w badaniu. Trzy lata później ponowiono wywiad na grupie 95\% respondentów 
z pierwszej fali badań. Wykorzystano te same instrumenty. Porównanie między wykluczonymi z drugiego wywiadu a respondentami ponownie badanymi wykazało nieznaczne różnice w zakresie zachowań przestępczych i zażywania narkotyków względem pierwszej fali. Analizę podłużną ograniczono do nieletnich w wieku 12 i 15 lat (pierwsza fala) oraz 15 i 18 lat (druga fala). Weryfikacja GST wymaga miar kontroli społecznej, zróżnicowanych powiązań oraz napięcia, gdyż negatywne relacje z innymi mogą stać się czynnikiem ryzyka zachowań przestępczych, nie tylko dzięki negatywnym emocjom i presji redukcji napięcia, ale również w wyniku niewystarczającej kontroli społecznej i uczenia się dziecka patologicznej aktywności.

Pojawiały się trudności w klasyfikacji zmiennych - jako miar kontroli społecznej czy też napięcia. Ostatecznie wskaźnikami kontroli społecznej zostały:

- przywiązanie rodzicielskie,

- liberalizm rodzicielski,

- przywiązanie szkolne,

- przywiązanie rówieśnicze,

- czas poświęcany na zadania domowe,

- oceny,

- cele edukacyjne.

Za wskaźnik zróżnicowanych powiązań posłużyła przestępczość wśród przyjaciół.

W grupie wskaźników napięcia wyróżniono:

- negatywne wydarzenia życiowe,

- kłopoty życiowe,

- negatywne relacje $\mathrm{z}$ dorosłymi,

- kłótnie rodzicielskie,

- problemy sąsiedzkie,

- brak sympatii u płci przeciwnej,

- napięcie zawodowe,

- napięcie dotyczące ubioru (Agnew, White, 1992).

Wskaźniki przestępczości i zażywania narkotyków: częstotliwość dopuszczania się aktów przestępczych w ciągu ostatnich 3 lat, badano skalą ogólnej przestępczości. Ilość zażywanych narkotyków na przestrzeni ostatniego roku zbadano, wykorzystując wskaźnik samoopisowy - zażywanie narkotyków (Agnew, White, 1992).

Pierwsza hipoteza zakładała, że istnieje zależność między wskaźnikami wszystkich typów napięcia a przestępczością i zażywaniem narkotyków przy stałych wskaźnikach zróżnicowanych powiązań i kontroli społecznej. Druga 
hipoteza mówiła, iż istnieje zależność między czynami przestępczymi i zażywaniem narkotyków a posiadaniem przyjaciół z kręgów przestępczych i niską samooceną (Agnew, White, 1992).

Okazało się, że przestępczość i zażywanie narkotyków są determinowane przede wszystkim takimi zmiennymi napięcia jak: negatywne zdarzenia życiowe oraz życiowe kłopoty. Istotne są także kłótnie rodzicielskie oraz negatywne relacje z dorosłymi, jednakże tylko w przypadku czynów karalnych. Odnośnie do zażywania narkotyków ważne miejsce zajmuje zmienna - problemy sąsiedzkie. Nieistotne okazały się wskaźniki dotyczące ubioru, braku sympatii u płci przeciwnej oraz pracy zawodowej. Ponadto istnieje zależność między przestępczością a ocenami, przywiązaniem rodzicielskim, szkolnym oraz czasem poświęcanym na zadania domowe (zmienne kontroli społecznej). Trzy ostatnie zmienne są również negatywnie powiązane z zażywaniem przez nieletnich narkotyków. Zaskakujące okazało się jednak to, iż przywiązanie rówieśnicze nie chroni (popycha) do zachowań przestępczych/zażywania narkotyków. Przestępczość wśród przyjaciół jest natomiast najsilniejszą zmienną predykcyjną, istotnie determinuje przestępczość i zażywanie narkotyków przez nieletnich. Weryfikacja drugiej hipotezy potwierdza, iż wraz ze wzrostem przyjaciół z kręgów przestępczych będzie wzrastać poziom przestępczości i zażywania narkotyków przez daną jednostkę. Niska samoskuteczność (postrzeganie własnej kontroli nad środowiskiem) może prowadzić do przestępczości, nie ma jednak związku z zażywaniem narkotyków. Nie do końca jest to uzasadnione. Przypuszczalnie osoby z niską samoskutecznością mają skłonność do redukcji napięcia przez działania agresywne, nie ma to jednak związku z zażywaniem narkotyków (Agnew, White, 1992).

Powyższe dane potwierdzają założenia ogólnej teorii napięcia. Wyniki są obiecujące. Dalsze badania powinny skupić się na wywiadach oraz obserwacjach, które mogą pomóc w ustaleniu typów negatywnych relacji (Agnew, White, 1992).

Wśród rodzimych przykładów zastosowań ogólnej teorii napięcia należy zwrócić uwagę na prace: Bylicy (Bylica, 2010), Czerwińskiej-Jakimiuk (Czerwińska-Jakimiuk, 2011) oraz Kowalczyk (Kowalczyk, 2010). Wyniki okazują się być obiecujące.

\section{Podstawy metodologiczne badań własnych}

Nieletni sprawcy przestępstw seksualnych stanowią niepospolitą grupę badawczą. Opracowując projekt badań, długo zastanawiałam się, jak ująć przedmiot 
poznania, by nawiązywał on do wcześniej omówionej teorii przy jednoczesnej możliwości zebrania rzetelnych danych.

Przedmiotem badań własnych uczynię nieletnich sprawców przestępstw seksualnych. Przedmiotem poznania natomiast będzie ich poczucie relacji rodzinnych. Interesujący dla mnie jest okres przed popełnieniem przestępstwa. Szczególnej uwadze zostaną poświęcone te relacje, które, w poczuciu nieletnich, zrodziły u nich negatywne napięcie motywacyjne. Jako że podmiotem badań uczynię samych sprawców - z punktu widzenia pracy interesujące stają się tylko te relacje, które odnoszą się do podmiotu, a więc:

- relacje nieletni-matka i matka-nieletni,

- nieletni-ojciec i ojciec-nieletni,

- nieletni-rodzeństwo i rodzeństwo-nieletni.

W przypadku, gdy nieletni będzie jedynakiem - badanie ograniczy się tylko do dwóch pierwszych konfiguracji relacji. Relacje z każdym z rodzeństwa będą badane oddzielnie.

Z punktu widzenia problemu badawczego nieistotne zdają się relacje między rodzicami, rodzicami a rodzeństwem nieletniego oraz samym rodzeństwem. Świadomie odrzucam te możliwości. Ponadto sprecyzowania wymaga także pojęcie rodziny. Dla potrzeb badań interesujący są tylko dla mnie ci nieletni, którzy wychowali się w rodzinach pełnych, w tym także zrekonstruowanych. Na uwagę zasługuje fakt, iż matką oraz ojcem nazywam te osoby, które w sposób faktyczny wychowywały nieletniego, co oznacza, iż nie muszą to być jego rodzice biologiczni. Niemniej jednak nie mogą być to inne osoby z rodziny nieletniego - dziadkowie czy pozostali krewni.

Relacje rodzinne obejmują cały wachlarz różnorodnych zagadnień. Stąd też wymagają sprecyzowania, jakie obszary są interesujące dla badacza. W projekcie tym chciałabym się skupić na pięciu obszarach relacji rodzinnych:

1) komunikacja (werbalna i niewerbalna),

2) postawy emocjonalne, behawioralne i poznawcze,

3) wspólne spędzanie czasu,

4) metody wychowawcze,

5) zaspakajanie potrzeb.

Myślę, że obszary te są na tyle złożone, iż dadzą bogaty obraz relacji rodzinnych nieletnich sprawców przestępstw seksualnych.

Celem badań jest poznanie i interpretacja poczucia relacji rodzinnych nieletnich sprawców przestępstw seksualnych w kontekście popełnionych przez nich czynów oraz wyjaśnienie rezultatów tychże relacji w świetle GST - ogólnej teorii napięcia Agnew, a także poznanie tła motywacyjnego popełnionych czy- 
nów. Celem praktyczno-wdrożeniowym będzie natomiast opracowanie projektu oddziaływań resocjalizacyjnych w stosunku do indywidualnych przypadków.

Główny problem badawczy w moim projekcie brzmi następująco: czym charakteryzowały się w poczuciu nieletnich sprawców przestępstw seksualnych ich relacje rodzinne, ze szczególnym uwzględnieniem relacji negatywnych (budzących negatywne napięcie motywacyjne) oraz czy pozostają one w związku $\mathrm{z}$ popełnionymi czynami?

Sformułowałam następujące problemy szczegółowe:

1. Jakie czynniki charakteryzowały, w poczuciu nieletnich, proces komunikacji (werbalne i niewerbalnej) z poszczególnymi członkami rodziny?

2. Jakie czynniki charakteryzowały, w poczuciu nieletnich, emocjonalne, behawioralne i poznawcze postawy poszczególnych członków rodziny wobec siebie nawzajem?

3. Jakie czynniki, w poczuciu nieletnich, charakteryzowały wspólnie spędzany czas w gronie rodziny?

4. Jakie czynniki, w poczuciu nieletnich, charakteryzowały metody wychowawcze (kary i nagrody) w rodzinach badanych?

5. Czy i jak zostawały zaspakajane potrzeby nieletnich, w ich poczuciu, przez poszczególnych członków rodziny?

6. Czy i jakie czynniki charakteryzujące rodzinne relacje nieletnich wywołały u nich, w ich poczuciu, ujemne napięcie motywacyjne i czy pozostają one w związku z popełnionymi czynami?

7. Jakie są cechy psychologiczne badanych sprawców?

8. Jakie były motywy działania sprawców?

9. Jakie działania można podjąć wobec badanych nieletnich przy uwzględnieniu tła motywacyjnego ich działania oraz czynników budzących ujemne napięcie motywacyjne?

Uwzględniając przedmiot i cele badań, zdecydowałam, iż metoda indywidualnych studiów przypadków będzie najtrafniejszą z repertuaru metod badawczych, jakimi posługują się pedagodzy.

W swoich badaniach posłużę się retrospektywną, instrumentalną metodą indywidualnych przypadków. Zbadanie wybranych jednostek będzie miało służyć powstaniu nowej wiedzy naukowej o badanym zjawisku. Badani będą odgrywać główną rolę w poznaniu zjawiska (Denzin, Lincoln, 2010), jakim są przestępstwa seksualne popełniane przez osoby nieletnie, natomiast relacje rodzinne w poczuciu owych nieletnich będą miały charakter pomocniczy. Badanie będzie miało charakter retrospektywny, gdyż nieletni będą opowiadać o okresie (o relacjach rodzinnych) przed popełnieniem danego przestępstwa. 
Myślę, iż tylko zastosowanie metody indywidualnych przypadków pomoże mi rozwiązać postawione wyżej problemy badawcze, tym samym zrealizować wysunięte cele.

Odpowiadającymi powyższej metodzie technikami badawczymi, którymi posłużę się w tym projekcie, będą: wywiad oraz analiza dokumentów.

Istnieje wiele rodzajów wywiadu. W swych badaniach posłużę się wywiadem nieustrukturyzowanym, swobodnym - ukierunkowanym, zwanym niekiedy pogłębionym. Dzięki niemu będą mogła spojrzeć na interesujące mnie zjawisko w sposób szerszy. Badanie nie zostanie ograniczone do zamkniętej listy pytań. Badacza posługującego się ową techniką charakteryzuje swoboda w zakresie zadawania pytań oraz ich formułowania - co jest zdeterminowane okolicznościami przeprowadzanego badania. Może on zmieniać kolejność, formę oraz treść pytań wobec każdego badanego przypadku. Ponadto posiada tylko pewne dyspozycje do wywiadu, pewną listę interesujących tematów. Język swobodnego wywiadu ukierunkowanego jest zbliżony do języka potocznego, nie jest sformalizowany ani ujednolicony. W trakcie badania mogą wyłonić się nowe, nieprzewidziane wątki, problemy, informacje, na co osoba badająca musi być otwarta i gotowa (Konecki, 2000).

Nie ma tu miejsca na skategoryzowany kwestionariusz wywiadu. Posłużę się jednak pewnymi dyspozycjami, będą nimi:

1) komunikacja (werbalna i niewerbalna),

2) postawy emocjonalne, behawioralne i poznawcze,

3) wspólne spędzanie czasu,

4) metody wychowawcze,

5) zaspakajanie potrzeb w następujących relacjach:

- nieletni-matka i matka-nieletni,

- nieletni-ojciec i ojciec-nieletni

- nieletni-rodzeństwo i rodzeństwo-nieletni.

Niezbędnym narzędziem będzie dobrej jakości dyktafon.

Kolejną techniką badawczą będzie analiza dokumentów, szeroko stosowana w pedagogice jako technika pomocnicza. Analizie poddam oficjalne dokumenty, jakie będą stanowić teczki badanych nieletnich. Znajdę tam diagnozę psychologiczną i psychiatryczną, cenne dane na temat cech osobowościowych nieletnich oraz bogaty zasób informacji o środowisku rodzinnym.

Dla omówionej procedury badawczej najwłaściwszy jest celowy dobór próby. Uzasadnia to zarówno strategia badań (jakościowa), jak i specyfika przypadków, ich cech oraz dostępności do nich. 


\section{Dlaczego GST? Aplikacje do badań własnych}

Pojęcie napięcia motywacyjnego jest zasadnicze w wyjaśnianiu zachowań przestępczych. Jednak nie pojawia się ono wyłącznie w ogólnej teorii napięcia Agnew. Stąd też pytanie - dlaczego GST stanowi podstawę teoretyczną projektowanych przeze mnie badań?

Klasyczne teorie napięcia (na charakterystykę których nie ma tu miejsca): teoria strukturalna Mertona (1938), teoria podkultur dewiacyjnych Cohena (1955) oraz teoria zróżnicowanych możliwości Clowarda i Ohlina (1960) zdominowały badania nad zjawiskiem przestępczości i zażywania narkotyków w latach sześćdziesiątych XX w. (Agnew, White, 1992). Po 10 latach znalazły się one pod obstrzałem ostrej krytyki, która dotyczyła głównie braku związku między czynnikami napięcia a zachowaniami przestępczymi/zażywaniem narkotyków. Pojawiały się wersje poprawione owej teorii, jednak dopiero GST Agnew tłumaczy wspomniane zachowania, bowiem opiera się ona na poprawionej wersji teorii napięcia, a także współczesnych badaniach z jej wykorzystaniem, z uwzględnieniem takich aspektów jak stres, sprawiedliwość oraz psychologiczne i socjologiczne badania nad agresją (Agnew, White 1992).

Merton doszukiwał się uwarunkowań zachowań dewiacyjnych w strukturze społecznej. Zachowania dewiacyjne były, jego zadaniem, reakcją na niekorzystną sytuację społeczną danej jednostki (sposobem redukcji napięcia i stanu anomii), która doświadczała rozbieżności między strukturą społeczną a kulturową (za: Siemaszko, 1993). Nurt krytyki tej teorii dotyczy przede wszystkim wyjaśniania głównie przestępczości przeciwko mieniu (Czerwińska-Jakimiuk, 2011). Podobnie rzecz ma się z teorią podkultur dewiacyjnych Cohena, gdzie podkreśla się nierówność szans w dostępie do realizacji celów społecznie pożądanych (przestępczość jako efekt rozładowania frustracji wywołanej rozbieżnościami systemu kulturowego). Natomiast Cloward i Ohlin doszukiwali się powstania stanu napięcia (będących przyczyną zachowań przestępczych) na skutek rozbieżności między aspiracjami jednostki a legalnymi możliwościami ich realizacji (za: Błachut, Gaberle, Krajewski, 1999).

Wszystkie te teorie prezentują strukturalne ujęcie napięcia, a GST Agnew koncentruje się na relacjach nieletnich z bliskimi (w tym na relacjach rodzinnych), zwracając szczególną uwagę na kontekst społeczno-psychologiczny. Wybór tej teorii do projektowanych przeze mnie badań jest uzasadniony, bowiem szczególną uwagę pragnę skupić na trzecim typie napięcia, tj. na negatywnych relacjach i czynnikach, które wywołały u nieletnich ujemne napięcie. 
W ogólnej teorii napięcia Agnew można wyodrębnić wiele zagadnień, a co za tym idzie - formułować wiele różnorodnych problemów badawczych dotyczących nie tylko czynników ryzyka zachowań przestępczych, także zażywania narkotyków, sposobów redukcji napięcia i wiele innych. $\mathrm{Z}$ tą teorią w tle badacz może posługiwać się zarówno strategiami ilościowymi, jak i jakościowymi, wykorzystać szeroki wachlarz metod: od sondażu diagnostycznego, przez eksperyment, aż do metody indywidualnych przypadków.

Uważam, że ogólna teoria napięcia Agnew spełnia wymogi stawiane przed teoriami, chociaż zdaję sobie sprawę z osobliwości wszystkich dziedzin wchodzących w skład nauk społecznych. Zastrzeżenia odnoszą się m.in. do charakteru tej teorii - czy jest abstrakcyjna - oraz języka - czy jest formalny. Zasięg GST jest wyraźnie ograniczony, lecz są określone jej warunki brzegowe. Podobnie rzecz się ma z testowalnością. Opierając się na tej teorii, będę starała się wyjaśnić, jak oraz dlaczego przebiegają interesujące mnie procesy. Czy w odniesieniu do konkretnego czasu historycznego i społecznej przestrzeni, a wyznacza ją nie to, co badał Agnew, lecz współczesne społeczeństwo polskie, teoria ta zachowa swoją wartość poznawczą i aplikacyjną? Jaka jest jej moc, zarówno wyjaśniająca, jak i predyktywna, w przypadku społeczeństwa znajdującego się w stanie ustrojowej transformacji?

Jak wskazuje sam autor - dalsze badania powinny skupić się na wywiadach oraz obserwacjach, które mogą pomóc w ustaleniu typów negatywnych relacji (Agnew, White, 1992).

Ogólna teoria napięcia zajmuje istotne miejsce także w pedagogice resocjalizacyjnej - w wyjaśnianiu etiologii przestępczości oraz w projektowaniu oddziaływań kompensacyjnych.

\section{Bibliografia}

Agnew R. (1992), Foundation for a general strain theory of crime and delinquency, „Criminology", vol. 30, issne 1, s. 47-87, DOI: http://dx.doi.org/10.1111/j.1745-9125.1992. tb01093.x.

Agnew R., White H. R. (1992), An empirical test of general strain theory, „Criminology”, vol. 30, no. 4, s. 475-499, DOI: http://dx.doi.org/10.1111/j.1745-9125.1992.tb01113.x.

Błachut J., Gaberle A., Krajewski K. (2001), Kryminologia, Wydawnictwo Arche, Gdańsk.

Bojarska K. (red.) (2012), Kodeks karny. Kodeks postępowania karnego. Kodeks karny wykonawczy. Kodeks karny skarbowy. Kodeks wykroczeń. Kodeks postępowania w sprawach o wykroczenia. Postępowanie $w$ sprawach nieletnich. Odpowiedzialność pod- 


\section{ORYGINALNE ARTYKUŁY BADAWCZE}

miotów zbiorowych za czyny zabronione pod groźba kary. Opłaty w sprawach karnych. Stan prawny na 10 kwietnia 2012 roku, Wydawnictwo LexisNexis, Warszawa.

Bylica J. (2010), Harmonizując napięcie: nowe spojrzenie $w$ profilaktyce uzależnień, Wydawnictwo Uniwersytetu Jagiellońskiego, Kraków.

Czerwińska-Jakimiuk E. (2011), Przestępczość młodocianych: interpretacja zjawiska w świetle ogólnej teorii napięcia Roberta Agnew, Wydawnictwo Naukowe Uniwersytetu Pedagogicznego, Kraków.

Denzin N. K., Lincoln I. S. (2010), Metody badań jakościowych, t. 1, Wydawnictwo Naukowe PWN, Warszawa.

Filar M. (1999), Przestęstwa seksualne w nowym polskim kodeksie karnym, „Problemy Rodziny”, nr 2-3, s. 53-58.

Filar M. (2004), Nowelizacja kodeksu karnego w zakresie tzw. przestępstw seksualnych, „Prokuratura i Prawo”, nr 11-12, s. 4.

Góral R. (1998), Kodeks karny. Praktyczny komentarz, Wydawnictwo Zrzeszenia Prawników Polskich, Warszawa.

Góral R. (2005), Kodeks karny. Praktyczny komentarz z orzecznictwem, Wydawnictwo Prawnicze, Warszawa.

Konecki K. (2000), Studia z metodologii badań jakościowych. Teoria ugruntowana, Wydawnictwo Uniwersytetu Szczecińskiego, Warszawa.

Kowalczyk M. H. (2010), Zabójcy i mordercy: czynniki ryzyka i możliwości oddziaływań resocjalizacyjnych, Oficyna Wydawnicza Impuls, Kraków.

Marek A. (2000), Komentarz do kodeksu karnego: część szczególna, Wydawnictwo Prawnicze, Warszawa.

Marzec-Holka K. (2011), Przemoc seksualna wobec dziecka: studium pedagogiczno-kryminologiczne, Wydawnictwo Impuls, Kraków.

Mozgawa M. (2006), Przestępstwa przeciwko wolności seksualnej i obyczajności (rozdz. XXV), w: M. Mozgawa (red.), Kodeks karny. Praktyczny komentarz, Wydawnictwo Kantor Wydawniczy Zakamycze, Kraków.

Pospiszyl K. (2005), Przestępstwa seksualne. Geneza, postacie, resocjalizacja oraz zabezpieczenia przed powrotnościa, Wydawnictwo Naukowe PWN, Warszawa.

Reykowski J. (1979), Emocje i motywacja, w: T. Tomaszewski (red.), Psychologia, Państwowe Wydawnictwo Naukowe, Kraków.

Siemaszko A. (1993), Granice tolerancji: o teoriach zachowań dewiacyjnych, Wydawnictwo Naukowe PWN, Warszawa.

Starowicz Z. L. (2007), Seksuologia sądowa, Wydawnictwo Lekarskie PZWL, Warszawa. 
Urban B. (2000), Zaburzenia w zachowaniu i przestępczość młodzieży, Wydawnictwo Uniwersytetu Jagiellońskiego, Kraków.

Wąsek A. (2006), Przestępstwa przeciwko wolności seksualnej i obyczajności (rozdz. XXV), w: A. Wąsek (red.), Kodeks karny: część szczególna. Komentarz do artykułów 117-221 , t. 1, Wydawnictwo C. H. Beck, Warszawa.

Wojciechowski J. (2000), Kodeks karny: komentarz, orzecznictwo, Wydawnictwo „Librata”, Warszawa.

\section{Netografia}

http://statystyka.policja.pl/st/wybrane-statystyki/przestepczosc-nieletni/50256, PRZESTEPCZOSC-NIELETNICH-w-LATACH-1990-2012.html (dostęp: 15.10.2013)

GST- General Strain Theory and juvenile perpetrators of sexual offences

\section{GST - General Strain Theory and juvenile perpetrators of sexual offenses}

\section{Summary}

The article discusses juvenile offenders and individuals taking drugs in the context of GST Robert Agnew's General Strain Theory. The unique character of this theory results from the fact that it is the only theory referring to negative relations as a risk factor for juvenile delinquency. Due to the author's interests, a special attention is placed on sex offenders. The paper explains legal aspects of these behaviours and basic terms arising from the theoretical concept in which the author decided to set her research.

Keywords: juvenile, motivation strain, family relations, general strain theory, sexual offences. 